\title{
Spiroplasma alleghenense sp. nov., a New Species from the Scorpion Fly Panorpa helena (Mecoptera: Panorpidae)
}

\author{
JEAN R. ADAMS, ${ }^{1}$ ROBERT F. WHITCOMB, ${ }^{2 *}$ JOSEPH G. TULLY, ${ }^{3}$ EDWARD A. CLARK, ${ }^{1}$ \\ DAVID L. ROSE,${ }^{3} \dagger$ PATRICIA CARLE,${ }^{4} \mathrm{M}$. KONAI, ${ }^{1}{ }^{\dagger} \mathrm{JOSEPH} M$ M. BOVÉ,${ }^{4}$ \\ ROBERTA B. HENEGAR, ${ }^{2}$ AND D. L. WILLIAMSON ${ }^{5}$ \\ Insect Biocontrol Laboratory, ${ }^{1}$ and Vegetable Laboratory, ${ }^{2}$ U. S. Department of Agriculture, Beltsville, Maryland 20705; \\ Mycoplasma Section, Laboratory of Molecular Microbiology, National Institute of Allergy and Infectious Diseases, \\ Frederick Cancer Research Facility, Frederick, Maryland 21702³ ; Laboratoire de Biologie Cellulaire \\ et Moléculaire, Institut Nationale de Recherche Agronomique, 33883 Villenave \\ d'Ornon Cedex, France ${ }^{4}$; and Department of Anatomical Sciences, State \\ University of New York, Stony Brook, New York $11794^{5}$
}

\begin{abstract}
Spiroplasma strain PLHS-1 ${ }^{\mathrm{T}}$ from the gut of a common scorpion fly (Panorpa helena) collected in the West Virginia Allegheny Mountains was distinct from other spiroplasma species, groups, and subgroups as determined by reciprocal serological metabolism inhibition and deformation tests. However, when this strain was used as an antigen, it cross-reacted extensively with representatives of other groups. Light microscopy and/or electron microscopy of cells of strain PLHS-1 ${ }^{\mathrm{T}}$ revealed helical motile cells surrounded by a single cytoplasmic membrane. The strain was resistant to penicillin, which confirmed that it had no cell wall. The organism grew well in M1D and SP-4 liquid media, in 1\% serum fraction medium, and in conventional horse serum medium. The optimum temperature for growth was $30^{\circ} \mathrm{C}$, at which the doubling time was $6.4 \mathrm{~h}$. Multiplication occurred at temperatures from 10 to $32^{\circ} \mathrm{C}$. Strain PLHS-1 ${ }^{\mathrm{T}}$ catabolized glucose, hydrolyzed arginine but not urea, and required sterol for growth. The guanine-plus-cytosine content of the DNA was $31 \pm 1 \mathrm{~mol} \%$, and the genome size was 1,465 kbp. Strain PLHS-1 (= ATCC 51752) is designated the type strain of a new species, Spiroplasma alleghenense.
\end{abstract}

The genus Spiroplasma $(18,25,27)$ is a presumably immense (9) assemblage of arthropod-associated helical wall-less procaryotes. Most of these organisms are associated with insects, in a variety of cycles (5-7). In 1980, a group classification system was proposed for the genus (11); later, criteria for recognition of groups were established (22). Recently, the number of recognized Spiroplasma groups has increased from 25 to 33 because of recognition of eight newly described strains of insect-related spiroplasmas (27). One of these strains, designated PLHS $-1^{\mathrm{T}}$ (group XXVI), was derived from a common scorpion fly, Panorpa helena (Mecoptera: Panorpidae). Currently, group XXVI spiroplasmas are known only from the Allegheny Mountains of West Virginia.

In this paper, we present the results of a taxonomic study of strain PLHS- $1^{\mathrm{T}}$, organized on the basis of the proposed (10) minimal requirements for assignment of binomial names to mollicutes. As a result of our studies, we designate group XXVI strain PLHS-1 (= ATCC 51752) the type strain of a new species, Spiroplasma alleghenense.

\section{MATERIALS AND METHODS}

Spiroplasma strains. Strain PLHS $-1^{\mathrm{T}}$ was isolated and cultivated by standard techniques (13) from hemolymph of a Planorpa helena scorpion fly collected by E. A. Clark along the Glady River near Bowden, W.Va. on 4 June 1986. Representative strains of all previously recognized groups and subgroups $(17,20,25$, 27 ), including the type strains of recognized species, were employed in serological comparisons.

Culture medium and cultivation techniques. Strain PLHS $-1^{\mathbf{T}}$ was selected from organisms grown in primary culture in M1D liquid medium (21) at $30^{\circ} \mathrm{C}$.

${ }^{*}$ Corresponding author. Mailing address: Vegetable Laboratory, Range 2, HH3, BARCW, Beltsville, MD 20705. Phone: (301) 5048339. Fax: (301) 504-6017.

$\dagger$ Present address: 8602 Cinnamon Creek, San Antonio, TX 78284.

¥ Present address: 9125 Tymat Court, Laurel, MD 20703.
After several early broth passages, the isolate was triply cloned (15). The clone selected was designated PLHS $-1^{\mathrm{T}}$ and was used in characterization studies. Other medium formulations employed included SP-4 (21), serum fraction broth supplemented with $1 \%$ bovine serum fraction (16), and conventional horse serum medium (21). Solid media were prepared by adding Noble agar (Difco Laboratories, Detroit, Mich.) to a final concentration of $3.0 \%$. Agar cultures were incubated at $30^{\circ} \mathrm{C}$ either aerobically or anaerobically (hydrogen GasPak system; BBL Microbiology Systems, Cockeysville, Md.). Temperature requirements for growth were assessed as described by Konai et al. (12).

Morphological studies. Cells of strain PLHS- $1^{\mathrm{T}}$ in the logarithmic phase were examined by dark-field microscopy at a magnification of $\times 1,250$. For electron microscopy (23), cells of the strain were grown in approximately $3 \mathrm{ml}$ of broth and pelleted by centrifugation. They were fixed for $2 \mathrm{~h}$ in $3 \%$ glutaraldehyde, postfixed in $1 \%$ osmium tetroxide for $1 \mathrm{~h}$, dehydrated in acetone, and embedded in Epon; the resulting preparations were sectioned with a Sorvall ultramicrotome, and the sections were stained with $1 \%$ aqueous uranyl acetate and Reynold's lead citrate and examined with a Philips model 400T electron microscope.

Sterol requirement. Sterol requirements for growth were determined by conventional methods (16) and by a modified broth culture dilution method (14).

Tests for biological and biochemical properties. The procedures used to study glucose fermentation (1) and hydrolysis of arginine (8) and urea (1) have been described previously. Filtration characteristics were determined in M1D broth by techniques described previously (15).

Serological tests. Antiserum to strain PLHS $-1^{\mathrm{T}}$ was raised in rabbits as previously described (26). Hyperimmune antisera to all previously established Spiroplasma species and groups (Table 1) were obtained from the reference collections at the Beltsville Agricultural Research Center and the National Institute of Allergy and Infectious Diseases laboratory in Frederick, Md. These antisera and strain PLHS-1 ${ }^{\mathrm{T}}$ were used in metabolism inhibition and deformation tests as described previously $(24,26)$.

Genomic analysis. The techniques used for extraction and purification of chromosomal DNA from strain PLHS-1 ${ }^{\mathrm{T}}$ have been described previously (4). The guanine-plus-cytosine content of purified DNA was determined by the buoyant density and melting temperature methods (3). The techniques used for genome size determination have been described previously (2). Purified DNA from Spiroplasma citri (genome size, approximately $1,820 \mathrm{kbp}$; guanine-pluscytosine content, $26 \pm 1 \mathrm{~mol} \%$ ) was used as a reference in all procedures (3).

\section{RESULTS AND DISCUSSION}

Cultural and morphological properties. Strain PLHS $-1^{\mathrm{T}}$ grew well in liquid M1D and SP-4 media and on solid SP-4 
TABLE 1. Serological reactions and cross-reactions of strain PLHS- $1^{T}$ in deformation and metabolis inhibition serological tests ${ }^{a}$

\begin{tabular}{|c|c|c|c|c|c|}
\hline \multirow{3}{*}{ Group } & \multirow{3}{*}{ Strain } & \multicolumn{4}{|c|}{ Titer in: } \\
\hline & & \multicolumn{2}{|c|}{$\begin{array}{c}\text { Spiroplasma } \\
\text { deformation test }\end{array}$} & \multicolumn{2}{|c|}{$\begin{array}{l}\text { Metabolism } \\
\text { inhibition test }\end{array}$} \\
\hline & & $\begin{array}{l}\text { Anti- } \\
\text { serum }\end{array}$ & Antigen & $\begin{array}{l}\text { Anti- } \\
\text { serum }\end{array}$ & Antigen \\
\hline $\mathrm{I}-1$ & $\mathrm{R} 8 \mathrm{~A} 2^{\mathrm{T}}$ & $0^{b}$ & $\sigma^{c}$ & $162^{d}$ & $0^{e}$ \\
\hline $\mathrm{I}-2$ & $\mathrm{BC}-3^{\mathrm{T}}$ & 0 & 0 & 54 & 0 \\
\hline I-3 & $\mathrm{E} 275^{\mathrm{T}}$ & 160 & 0 & 162 & 0 \\
\hline I-4 & $277 \mathrm{~F}$ & 20 & 0 & 54 & 0 \\
\hline $1-5$ & LB-12 & 80 & 0 & 54 & 0 \\
\hline$I-6$ & M55 & 0 & 0 & 162 & 0 \\
\hline $\mathrm{I}-7$ & N525 & 20 & 0 & 54 & 0 \\
\hline $\mathrm{I}-8$ & $\mathrm{P} 40^{\mathrm{T}}$ & 40 & 0 & 54 & 0 \\
\hline II & DW-1 & 0 & 0 & 54 & 0 \\
\hline III & $23-6^{\mathrm{T}}$ & 80 & 0 & 162 & 0 \\
\hline IV & $\mathrm{B} 31^{\mathrm{T}}$ & 40 & 0 & 162 & 0 \\
\hline $\mathrm{V}$ & $\mathrm{SMCA}^{\mathrm{T}}$ & 0 & 0 & 162 & 0 \\
\hline VI & $\mathrm{Y} 32^{\mathrm{T}}$ & 0 & 0 & 162 & 0 \\
\hline VII & $M Q-1^{T}$ & 40 & 0 & 54 & 0 \\
\hline VIII-1 & EA- $1^{\mathrm{T}}$ & 0 & 0 & 18 & 0 \\
\hline VIII-2 & $\mathrm{DF}-1^{\mathrm{T}}$ & 0 & 0 & 162 & 0 \\
\hline VIII-3 & TAAS-1 & 0 & 0 & 54 & 0 \\
\hline IX & $\mathrm{CN}-5^{\mathrm{T}}$ & 0 & 0 & 162 & 0 \\
\hline$X$ & $\mathrm{AES}-1^{\mathrm{T}}$ & 80 & 0 & 54 & 0 \\
\hline XI & $\mathrm{MQ}-4^{\mathrm{T}}$ & 80 & $20(640)^{f}$ & 54 & 0 \\
\hline XII & DU-1 ${ }^{\mathrm{T}}$ & 80 & 0 & 162 & 0 \\
\hline XIII & $\operatorname{Ar} 1343^{\mathrm{T}}$ & 160 & 0 & 162 & 0 \\
\hline XIV & $\mathrm{EC}-1^{\mathrm{T}}$ & 80 & 0 & 162 & 0 \\
\hline XV & $\mathrm{I}-25$ & 40 & 0 & 162 & 0 \\
\hline XVI-1 & $\mathrm{CC}-1^{\mathrm{T}}$ & 160 & 0 & 162 & 0 \\
\hline XVI-2 & CB-1 & 20 & 0 & 18 & 0 \\
\hline XVI-3 & Ar 1357 & 80 & 0 & 54 & 0 \\
\hline XVIII & TN-1 ${ }^{\mathrm{T}}$ & 20 & 0 & 162 & 0 \\
\hline XIX & PUP-1 $^{\mathrm{T}}$ & 0 & $20(10,240)$ & 162 & $486(117,000)$ \\
\hline XX & $\mathrm{LD}-1^{\mathrm{T}}$ & 0 & $40(20,480)$ & 162 & $18(117,000)$ \\
\hline XXI & W115 & 0 & 0 & 162 & 0 \\
\hline XXII & $\mathrm{CT}-1^{\mathrm{T}}$ & 160 & 0 & 54 & 0 \\
\hline XXIII & TG-1 ${ }^{\mathbf{T}}$ & 20 & 0 & 54 & 0 \\
\hline XXIV & $\mathrm{CCH}^{\mathrm{T}}$ & 80 & 0 & 162 & 0 \\
\hline XXV & CUAS- $1^{\mathrm{T}}$ & 0 & $20(640)$ & 162 & 0 \\
\hline XXVI & PLHS-1 ${ }^{T}$ & $2,560^{g}$ & 2,560 & $117,000^{g}$ & 117,000 \\
\hline XXVII & TALS $-1^{\mathrm{T}}$ & 40 & 0 & 54 & 0 \\
\hline XXVIII & PALS-1 ${ }^{\mathrm{T}}$ & 0 & 0 & 162 & 0 \\
\hline XXIX & TIUS-1 & 0 & 0 & 162 & 0 \\
\hline $\mathrm{XXX}$ & BIUS-1 & 40 & 0 & 1,458 & 0 \\
\hline XXXI & HYOS-1 ${ }^{\mathrm{T}}$ & 40 & 0 & 162 & 0 \\
\hline XXXII & TABS-2 $2^{T}$ & 0 & 0 & 54 & 0 \\
\hline XXXIII & TAUS- $1^{\mathrm{T}}$ & 0 & 0 & 162 & 0 \\
\hline
\end{tabular}

${ }^{a}$ Antigens and antisera of the strains were tested in all combinations against representatives of all known and putative groups and subgroups. All crossreactions except those shown were negative. Negative reactions (value, 0 ) were determined at thresholds of 1:20 and 1:18 for the deformation and metabolism inhibition tests, respectively.

${ }^{b}$ Reciprocal of the endpoint in a deformation test in which the antigen was tested against antiserum against strain PLHS-1 ${ }^{\mathrm{T}}$.

${ }^{c}$ Reciprocal of the endpoint in a deformation test in which the antiserum was tested against strain PLHS-1 ${ }^{\mathrm{T}}$ antigen.

${ }^{d}$ Reciprocal of the endpoint in a metabolism inhibition test in which the antigen was tested against antiserum against strain PLHS- $1^{\mathrm{T}}$.

${ }^{e}$ Reciprocal of the endpoint in a metabolism inhibition test in which the antiserum was tested against strain PLHS $-1^{\mathbf{T}}$ antigen.

${ }^{f}$ The number in parentheses is the reciprocal of the endpoint for the homologous antiserum against which strain PLHS-1 ${ }^{\mathbf{T}}$ antigen was tested.

${ }^{g}$ Homologous titer of the strain in the test system. This titer, obtained only once, is included for completeness.

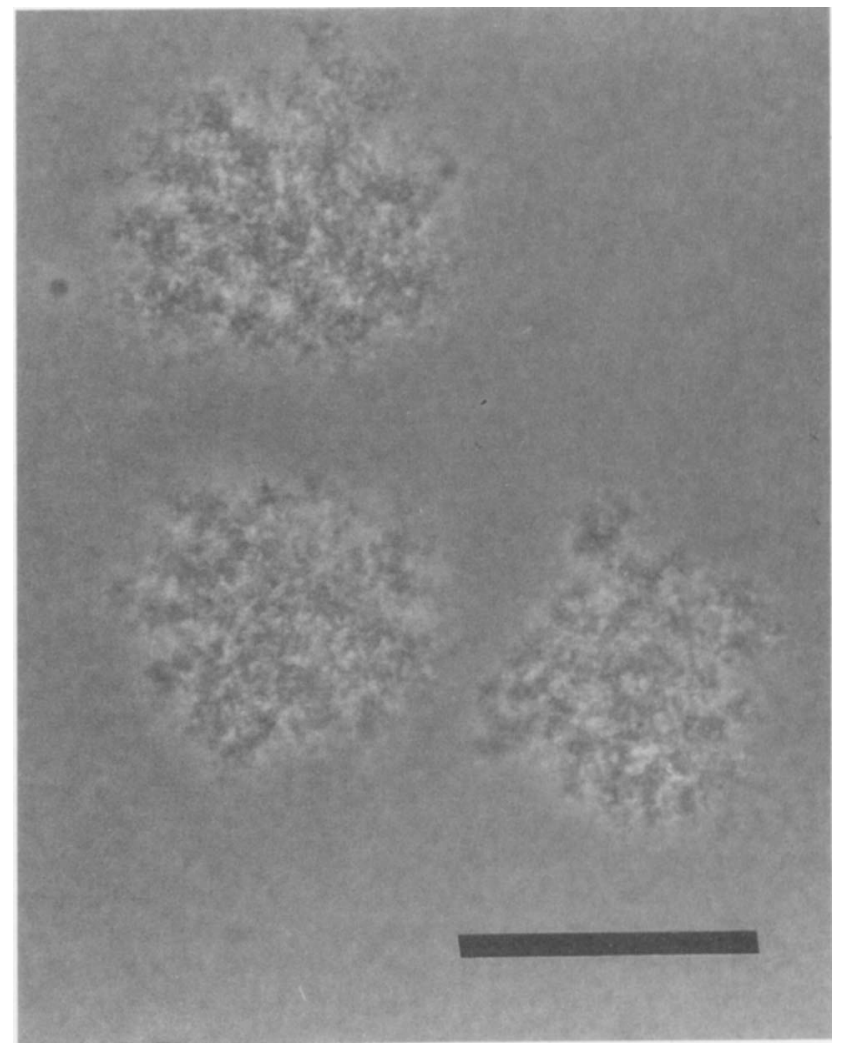

FIG. 1. Colonies of strain PLHS-1 $1^{\mathrm{T}}$ on SP-4 agar after 18 days of incubation at $30^{\circ} \mathrm{C}$ under anaerobic conditions. Bar $=50 \mu \mathrm{m}$

medium. The strain also grew in the Edward formulation of conventional mycoplasma medium containing $15 \%$ horse serum or in $1 \%$ bovine serum fraction medium. The strain grew at 10 to $32^{\circ} \mathrm{C}$; optimum growth with a doubling time of $6.4 \mathrm{~h}$ was observed at $30^{\circ} \mathrm{C}$ in M1D broth. No growth was observed during 3 weeks of incubation in M1D broth at 5 or $37^{\circ} \mathrm{C}$. Growth of strain PLHS- ${ }^{\mathrm{T}}$ on solid medium was observed on agar plates. Colonies of strain PLHS-1 ${ }^{\mathrm{T}}$ on SP-4 agar were diffuse on the usual "hard" agar (2.25\% agar); however, when the agar concentration was increased to $3.0 \%$, small granular colonies with irregular edges formed after incubation for 18 days at $30^{\circ} \mathrm{C}$ under anaerobic conditions (Fig. 1). Colonies with a fried-egg morphology were never observed.

As determined by dark-field microscopy, logarithmic-phase cultures of strain PLHS- $1^{\mathrm{T}}$ in M1D medium contained long helical motile filaments, most of which had six or more turns. Cells of the organism sedimented from broth cultures and examined by electron microscopy were filamentous, with no evidence of a cell wall (Fig. 2). Representative cells were 100 to $300 \mathrm{~nm}$ in diameter and were bounded by a single cytoplasmic membrane.

Sterol requirement. The responses of strain PLHS- $1^{\mathrm{T}}$ to cholesterol supplementation of serum-free SP-4 medium are shown in Table 2. No growth was apparent in base broth alone, but growth was enhanced when $5 \mu \mathrm{g}$ of cholesterol per ml was included. Lower concentrations of cholesterol did not stimulate growth, and higher concentrations were inhibitory. As determined by the modified serial dilution method, strain PLHS- ${ }^{\mathrm{T}}$ grew well in medium containing fetal bovine serum, but failed to grow in serum-free medium. This strain therefore requires serum or cholesterol. 


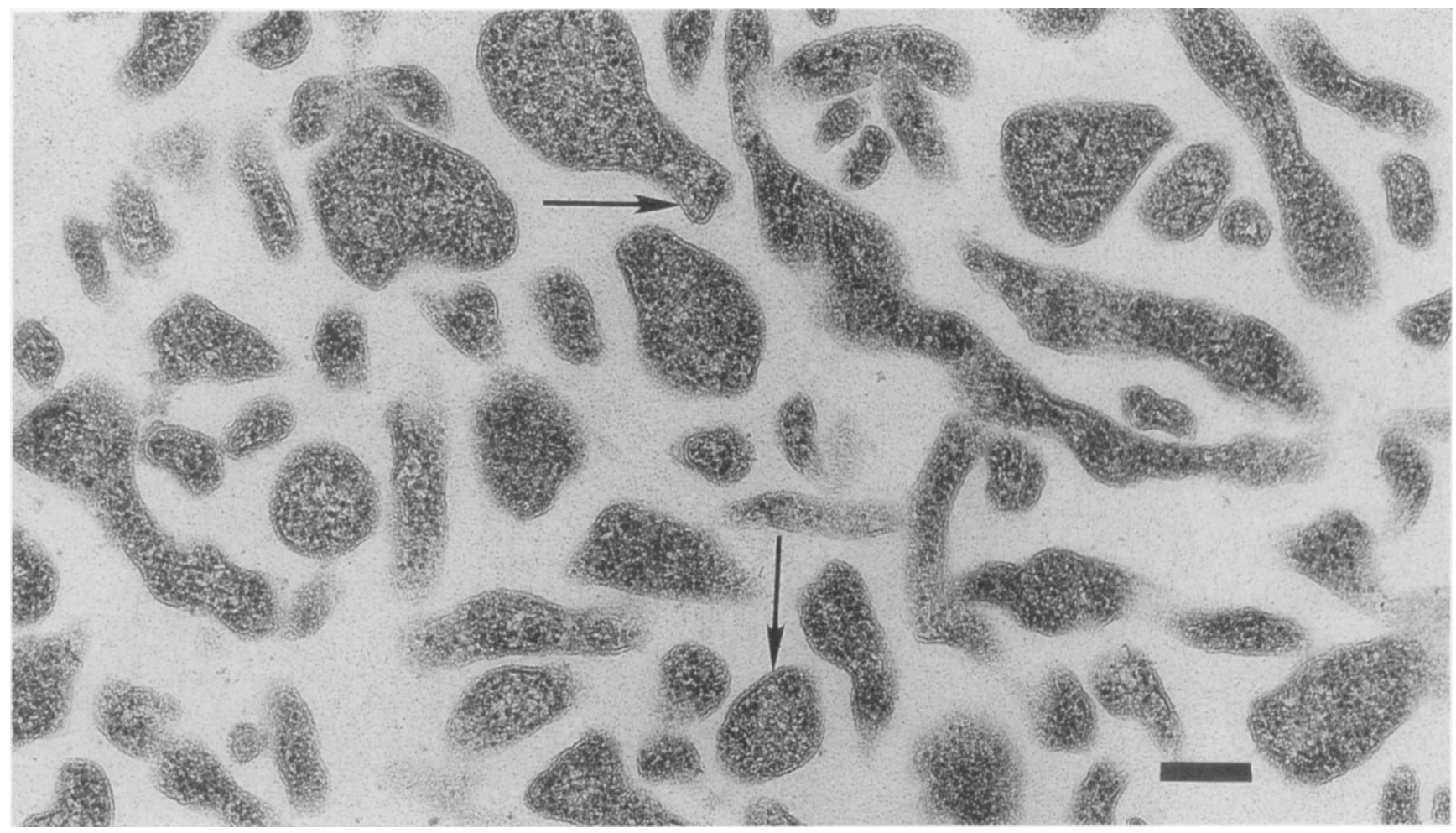

FIG. 2. Electron micrograph of a section of a pellet of strain PLHS-1 $1^{T}$ cells. Arrows indicate the unit membrane. Bar $=200 \mathrm{~nm}$.

Biochemical and biological properties. Strain PLHS $-1^{\mathrm{T}}$ produced acid from glucose and hydrolyzed arginine but not urea. Passage of broth cultures of strain PLHS $-1^{\mathrm{T}}$ through $450-\mathrm{nm}-$ pore-size membrane filters reduced the viable cell titer from $10^{9}$ to $10^{8}$ color-changing units $/ \mathrm{ml}$. The titer of a broth culture filtrate obtained after passage through a $300-\mathrm{nm}$-pore-size membrane filter was also reduced about 10 -fold (to $10^{7}$ colorchanging units $/ \mathrm{ml}$ ). Passage through $220-\mathrm{nm}$ filter pores reduced the titer by $3 \log _{10}$ units. The $100-n m-$ pore-size membrane filtrate did not contain viable cells.

Serological tests. The results of metabolism inhibition and spiroplasma deformation tests (Table 1) indicated that strain PLHS $-1^{\mathrm{T}}$ was not related serologically to representatives of previously established groups or species of the genus Spiroplasma. However, when the strain was used as an antigen, it exhibited a broad pattern of nonspecific one-way cross-reactions in both metabolism inhibition and deformation tests.

Genome size and DNA base composition. The base composition (guanine-plus-cytosine content) of PLHS- ${ }^{\mathrm{T}}$ DNA was $31 \pm 1 \mathrm{~mol} \%$. The genome size was determined to be 1,465 kbp.

Habitat. The single strain described here was isolated directly from the gut of the common scorpion fly $P$. helena. Strain PLHS $-1^{\mathrm{T}}$ is not known to be pathogenic to its insect host. In addition to the type strain, seven isolates referrable to $S$. alleghenense were obtained from five adult male and female individuals of $P$. helena. The five collections represented three locations in riparian habitats of two tributaries (the Glady and Dry Forks) of the Cheat River in the Allegheny Mountains of West Virginia's Randolph County. Spiroplasmas were observed in both blood and gut fluids. Two males and a female collected on 4 June 1986 yielded cultures. One of these cultures, BARC 0006, from the gut of a female, was triply cloned, leading to strain PLHS- $1^{\mathrm{T}}$. Exactly 1 year after the first collec- tions, two additional collections, BARC 0292 and BARC 0293, from a male and a female, were also made. Only one isolate (the type strain) was cloned, but serological analyses of the other isolates, BARC 005, BARC 006 Regurgitated Gut Fluids, BARC 0007, BARC 0292 blood, BARC 0292 gut, BARC 0293 blood, and BARC 0293 gut, exhibited titers of 1,280 to 2,560 against antiserum directed against strain PLHS- ${ }^{\mathrm{T}}$.

The properties of strain PLHS- $1^{\mathrm{T}}$ described here fulfill proposed criteria (10) for species of the class Mollicutes, including absence of a cell wall, filterability, lack of reversion to walled bacteria when the organism is grown in antibiotic-free media, and penicillin resistance. The helicity and motility of strain PLHS $-1^{\mathrm{T}}$ and its inability to utilize urea place this organism in the family Spiroplasmataceae of the order Entomoplasmatales (19). Finally, a serological comparison of strain PLHS $-1^{\mathrm{T}}$ with other Spiroplasma species demonstrated the uniqueness of the new insect strain. We therefore propose the name Spiroplasma alleghenense for this organism. The taxonomic description below summarizes the properties of this organism.

TABLE 2. Growth response of strain PLHS $-1^{\mathrm{T}}$ to cholesterol

\begin{tabular}{lcc}
\hline \multicolumn{1}{c}{ Medium } & $\begin{array}{c}\text { Cholesterol concn } \\
(\mu \mathrm{g} / \mathrm{ml})\end{array}$ & $\begin{array}{c}\text { Amt of protein } \\
(\mathrm{mg} / 100 \mathrm{ml})\end{array}$ \\
\hline M1D (control) & & 1.32 \\
Serum free & 0 & $\mathrm{IG}^{a}$ \\
& 1 & $\mathrm{IG}$ \\
& 2 & 0.23 \\
& 5 & 1.20 \\
& 10 & $\mathrm{IG}$ \\
& 20 & 0.25 \\
\hline
\end{tabular}

${ }^{a} \mathrm{IG}$, insufficient growth. 
Description of Spiroplasma alleghenense sp. nov. Spiroplasma alleghenense (al.le.ghen.en'se. M.L. n. alleghenense, of the Allegheny Mountains, referring to the geographic origin of the type strain, the range of the Appalachian Mountains from which it was derived).

Cells are helical, motile filaments that vary from 100 to 300 $\mathrm{nm}$ in diameter. The cells lack true cell walls. Colonies on SP-4 solid medium containing 3.0\% Noble agar are small and granular and never have a fried-egg appearance.

Chemoorganotroph. Acid is produced from glucose. Hydrolyzes arginine but not urea.

Cholesterol or serum is required for growth.

The temperature range for growth is 10 to $32^{\circ} \mathrm{C}$, and optimum growth occurs at $32^{\circ} \mathrm{C}$. The doubling time at the optimum temperature in M1D medium is $6.4 \mathrm{~h}$.

Serologically distinct from other established Spiroplasma species. Isolated from the hemolymph of a common scorpion fly, Panorpa helena. Pathogenicity for insects has not been determined.

The guanine-plus-cytosine content of the DNA is $31 \pm 1$ mol\%, and the genome size is $1,465 \mathrm{kbp}$.

The type strain is PLHS-1 (= ATCC 51742).

\section{ACKNOWLEDGMENT}

We thank Jeffrey Buller, Georgia Southern University, Statesboro, for his advice concerning the Latin name.

\section{REFERENCES}

1. Aluotto, B. B., R. G. Wittler, C. O. Williams, and J. E. Faber. 1970. Standardized bacteriologic techniques for characterization of Mycoplasma species. Int. J. Syst. Bacteriol. 20:35-58.

2. Carle, P., F. Laigret, J. G. Tully, and J. M. Bové. 1995. Heterogeneity of genome sizes within the genus Spiroplasma. Int. J. Syst. Bacteriol. 45:178181.

3. Carle, P., C. Saillard, and J. M. Bové. 1983. Determination of guanine plus cytosine content of DNA. Methods Mycoplasmol. 1:301-308.

4. Carle, P., C. Saillard, and J. M. Bové. 1983. DNA extraction and purification. Methods Mycoplasmol, 1:295-299.

5. Clark, T. B. 1982. Spiroplasmas: diversity of arthropod reservoirs and hostparasite relationships. Science 212:57-59.

6. Clark, T. B. 1984. Diversity of spiroplasma host-parasite relationships. Isr. J. Med. Sci. 20:995-997.

7. Hackett, K. J., and T. B. Clark. 1989. Ecology of spiroplasmas, p. 113-200. In R. F. Whitcomb and J. G. Tully (ed.), The mycoplasmas, vol. 5. Academic Press, San Diego, Calif.

8. Hackett, K. J., E. A. Clark, R. F. Whitcomb, M. Camp, and J. G. Tully. 1996. Amended data on arginine utilization by Spiroplasma species. Int. J. Syst. Bacteriol, 46:912-915.

9. Hackett, K. J., R. F. Whitcomb, R. B. Henegar, A. G. Wagner, E. A. Clark, J. G. Tully, F. Green, W. H. McKay, P. Santini, D. L. Rose, J. J. Anderson, and D. E. Lynn. 1990. Mollicute diversity in arthropod hosts. Zentralbl. Bakteriol. Hyg. Suppl. 20:441-454.
10. International Committee on Systematic Bacteriology Subcommittee on the Taxonomy of Mollicutes. 1995. Revised minimal standards for descriptions of new species of the class Mollicutes (division Tenericutes). Int. J. Syst. Bacteriol. 45:605-612

11. Junca, P., C. Saillard, J. Tully, O. Garcia-Jurado, J. R. Degorce-Dumas, C Mouches, J. C. Vignault, R. Vogel, R. McCoy, R. Whitcomb, D. Williamson, J. Latrille, and J. M. Bové. 1980. Caractérisation de spiroplasmes isolés d'insectes et de fleurs de France continentale, de Corse, et du Maroc: proposition pour une classification des spiroplasmes. C. R. Acad. Sci. Ser. D 290:1209-1212.

12. Konai, M., E. A. Clark, and R. F. Whitcomb. 1996. Temperature ranges and growth optima of Spiroplasma (Spiroplasmataceae; class Mollicutes). Curr Microbiol. 32:1-7.

13. Markham, P. G., T. B. Clark, and R. F. Whitcomb. 1983. Culture techniques for spiroplasmas from arthropods. Methods Mycoplasmol. 2:217-223.

14. Rose, D. L., J. G. Tully, J. M. Bové, and R. F. Whitcomb. 1993. A test for measuring growth responses of mollicutes to serum and polyoxyethylene sorbitan. Int. J. Syst. Bacteriol. 43:527-532.

15. Tully, J. G. 1983. Cloning and filtration techniques for mycoplasmas. Methods Mycoplasmol. 1:173-177.

16. Tully, J. G. 1995. Determination of cholesterol and polyoxyethylene sorbitan growth requirements of mollicutes, p. 381-389. In S. Razin and J. G. Tully (ed.), Molecular and diagnostic procedures in mycoplasmology, vol. 1. Academic Press, San Diego, Calif.

17. Tully, J. G., J. M. Bové, F. Laigret, and R. F. Whitcomb. 1993. Revised taxonomy of the class Mollicutes: proposed elevation of a monophyletic cluster of arthropod-associated mollicutes to ordinal rank (Entomoplasma tales ord. nov.), with provision for familial rank to separate species with nonhelical morphology (Entomoplasmataceae fam. nov.) from helical species (Spiroplasmataceae), and emended descriptions of the order Mycoplasmatales, family Mycoplasmataceae. Int. J. Syst. Bacteriol. 43:378-385.

18. Tully, J. G., and S. Razin (ed.). 1996. Molecular and diagnostic procedures in mycoplasmology, vol. 2, p. 460-462. Academic Press, San Diego, Calif.

19. Tully, J. G., D. L. Rose, E. Clark, P. Carle, J. M. Bové, R. B. Henegar, R. F. Whitcomb, D. E. Colflesh, and D. L. Williamson. 1987. Revised group classification of the genus Spiroplasma (class Mollicutes), with proposed new groups XII to XXIII. Int. J. Syst. Bacteriol. 37:357-364.

20. Tully, J. G., and R. F. Whitcomb. 1991. The genus Spiroplasma, p. 19601980. In A. Balows, H. G. Trüper, M. Dworkin, W. Harder, and K. H. Schleifer (ed.), The prokaryotes, 2nd ed., vol. 2. Springer-Verlag, New York N.Y.

21. Whitcomb, R. F. 1983. Culture media for spiroplasmas. Methods Mycoplasmol. 1:147-158

22. Whitcomb, R. F., J. M. Bové, T. A. Chen, J. G. Tully, and D. L. Williamson. 1987. Proposed criteria for an interim serogroup classification for members of the genus Spiroplasma (class Mollicutes). Int. J. Syst. Bacteriol. 37:82-84.

23. Williamson, D. L. 1983. Specialized electron microscopic techniques for spiroplasmas in plant and insect tissues. Methods Mycoplasmol. 1:71-76.

24. Williamson, D. L., J. G. Tully, and R. F. Whitcomb. 1979. Serological rela tionships of spiroplasmas as shown by combined deformation and metabolism inhibition tests. Int. J. Syst. Bacteriol. 29:345-351.

25. Williamson, D. L., J. G. Tully, and R. F. Whitcomb. 1989. The genus Spiroplasma, p. 71-111, In R. F. Whitcomb and J. G. Tully (ed.), The mycoplasmas, vol. 5. Academic Press, San Diego, Calif.

26. Williamson, D. L., R. F. Whitcomb, and J. G. Tully. 1978. The spiroplasma deformation test, a new serological method. Curr. Microbiol. 1:203-207.

27. Williamson, D. L., R. F. Whitcomb, J. G. Tully, G. E. Gasparich, D. L. Rose P. Carle, J. M. Bove, K. J. Hackett, R. B. Henegar, M. Konai, C. Chastel, and F. E. French. 1997. IOM Lett. 4:217. 